\title{
Successful Internet Entrepreneurs: The Case of China
}

\author{
Ayoub Zouria ${ }^{1}$, Michael Uche Udanoh $^{2}$ \\ ${ }^{1}$ Lecturer at Tourism College of Zhejiang, School of Business Administration, Hangzhou, China \\ ${ }^{2}$ Program Coordinator/ Educator at Wesley School, Hangzhou, China \\ Correspondence: Ayoub Zouria, Lecturer at Tourism College of Zhejiang, School of Business Administration, Hangzhou, \\ China.
}

Received: December 17, 2019

Accepted: January 9, 2020

Available online: January 21, 2020

doi:10.11114/ijsss.v8i2.4659

URL: https://doi.org/10.11114/ijsss.v8i2.4659

\begin{abstract}
Internet is without any doubt playing a significant role in businesses as well as peoples' lives. Many individuals nowadays choose to use the internet while undertaking different tasks. Internet is the product of the ever-advancing technology which has resulted to means of interconnecting various computers.

This article focuses on the significance of internet and how it helped many entrepreneurs become successful. It sheds light on the case of the Chinese entrepreneurs that have seen their businesses booming thanks to the use of websites which are products of internet to compete and market their products across the world.
\end{abstract}

Keywords: entrepreneurship, internet, China, technology, innovation

\section{Introduction}

Internet is undoubtedly playing huge role in businesses and peoples' lives. Many individuals in the present-day world rely on internet in undertaking different tasks. Internet is the product of the ever-advancing technology which has resulted to means of interconnecting various computers. Internet is described as a very versatile facility which can assist in completing numerous tasks in a more convenient and easy way with just few clicks (Donaldson, 2016). Almost everything is currently available over the internet thanks to the growth in technology. Recently, individuals and businesses are looking for information over the internet. People are seeking for possible solution to their problems and are satisfactorily getting solutions (Hosu \& Iancu, 2016). One can pay bills over the internet, purchase items, communicate and seek important information regarding various problems. Internet is explained as the global computer network offering variety of communication and information facilities comprising of interconnected networks by the use of standardized communication protocol (Blank, 2017). It is also the means of connecting computers anywhere across the world through dedicated servers and routers.

Internet started being used from the last five decades. Ever since, internet has changed every aspect in the lives of people across the world. Living in the 21st century, internet makes almost everything possible; Research, communication, teaching and shopping are being done online (Blank, 2017). Almost all the human interest such as business has drastically been impacted with internet use. Businesses are making use of websites which are products of internet to compete and market their products across the world (DeLisle, Goldstein \& Yang, 2016). Business owners are marketing there businesses online in order to have their business and services known by many. Internetworldstats.com website showed that there are over 7 billion internet users across the world. This made various businesses adopt internet and online strategies in order to reach out to the billions of individuals in various online platforms.

Internet enables companies to communicate fast, access information faster, access all manner of information and support the growth of business because marketing and promotional effort are made effective (Blank, 2017). Due to massive spread of internet usage, various platforms such as social media sites came into being. People are interacting and communicating online using internet. Billions of online users have prompted businesses to make use of internet as a way of reaching out to them in order to create awareness, provoke purchase and entice users into buying their products (DeLisle, Goldstein \& Yang, 2016). Therefore, it can be concluded that business would be impossible without internet. This is because internet is one of the most crucial marketing tools used in the modern business world. Internet is helping companies to attain goals, grow and become more successful in the current dynamic and competitive economic world. 


\section{How Internet is Supporting Entrepreneurs}

In 1990, the internet revolution took off. This led to widespread access to information which in turn made the world so smaller. Simple self-expressions and ideas would be passed to numerous people within a short period of time. This led to emergence of a phase known as democratization of entrepreneurs. Sudden access to new ideas, new audience and associated low costs overhead made it easier to start business online (Blank, 2017). This is the main reason why entrepreneurs are flocking to the challenge in order to benefit from the internet usage. Internet Company requires little funds to start. Unlike other business where an entrepreneur will need to have sufficient cash, internet business has an equalizing power. The business has very little set up overheads and costs. This is because all what is required is just setting up a website. Site setting in the current business world is extremely affordable and can just take a day (DeLisle, Goldstein \& Yang, 2016). Company's website does not need extensive web design or coding knowledge. An online business can be run from one's house without having to look large premises. Small startup companies can easily compete with large companies because all what matters is the quality of service and products the company offers to the general publics.

Marketing is also cheap. In online businesses, an entrepreneur does not need to pay out thousands of dollars for a traditional mode of advertising. It is possible to market and promote a brand using social media. There are millions of people online and this provides an avenue to undertake massive promotion. Through internet usage, entrepreneurs are able to introduce market and create awareness. It is also worth noting that internet can give ideas very quick momentum (Hosu \& Iancu, 2016). Controversial tweets and videos turn viral within short period. This shows that entrepreneurs can benefit from how things happen so fast. Although it normally takes time to build website traffic, once individuals start to notice the company, it will gain acceptance. Therefore, through the above described ways, it is evident that internet is supporting entrepreneurs in the world.

\section{Internet Entrepreneurship in China}

The Chinese economy is among the current leading economies in the world. It is the second largest economy in the world after USA. This is contributed by prominent Chinese entrepreneurs who have greatly explored available business opportunities and strived to make their visions come into a reality. However, due to huge number of internet users in China, many entrepreneurs invested in online businesses. Take for instance, at the moment there are approximately 730 million internet users in China (Feng \& Wenjing, 2017). This means that more than half of its population is online. Entrepreneurs who were opportunistic enough and saw an opportunity present itself proactively took up the challenge and undertook online business (DeLisle, Goldstein \& Yang, 2016). Internet entrepreneurs started emerging in 1990s. Some of the businesses which emerged due to internet usage in China include Tencent, Baidu and Alibaba. The entrepreneurs saw the opportunity in the online business and decided to take advantage. These businesses have been successful ever since their establishment.

Through internet, various businesses have been successful in China. Alibaba.com was established by Jack Ma. This internet entrepreneur started by creating an internet website known as China pages and he faced major challenges in convincing people about the website as internet usage had not taken shape. During that period, people never thought that internet would one day be a key factor to improve businesses. As days passed by and Chinese economy continued to grow rapidly, computers started being useful in the daily business activities. This formed a breakthrough for Jack Ma's Alibaba business.

\section{Brief History of Alibaba}

Alibaba was formed in 1999 by Jack Ma in Hangzhou before launching Alibaba.com later in the same year. The number of internet users in China rose to 80 million by 2003 and this led Jack Ma to launch online market Taobao.com. The website was established as a result of the ever-growing number of internet users. The number of internet users continued rising and by 2007 Alimama was launched as a platform for undertaking advertising platforms. In 2008, Tmall was introduced as Alibaba ran B2B and C2C internet platforms (DeLisle, Goldstein \& Yang, 2016). At the moment, Alibaba is the largest online company in China. Due to massive success as a result of increased internet usage in China, the company operates in three major sites; Taobao, which is the largest shopping site; Tmall, which is a site specializing on online sales of branded product and mainly focuses on fast growing middle class Chinese; and Alibaba which connects and links exporters from China with the rest of companies from all over the world.

\section{How Internet Helped Alibaba}

Alibaba was formed by Jack Ma in 1999. During this time, few people had adopted internet. The internet had not gained a lot of importance in the world. Individuals and business never thought that one day internet would become a crucial success factor (Legaspi, 2017). As time passed by, people in China started appreciating the need for internet. China, with the largest population in the world and with majority of people using internet, online companies were bound to 
emerge. More people using internet offered the market for Alibaba Company. Jack Ma, seeing the opportunity he set up the first B2B business where its services and products were provided via internet platforms. After the formation of the company, Jack Ma targeted the majority of the Chinese internet users. He had forecasted that the internet usage would continue to grow in China. He studied the online market and realized that through internet it would be easy to reach to almost half of the Chinese population. Internet enables companies to communicate access information, undertake market research and get feedback from the consumers (Blank, 2017). The company would analyze the changing trends in the consumer market and strive to provide product and services according to consumer needs preferences.

Alibaba used internet to promote its products and services. Because majority of the Chinese are active internet users, the company would advertise and create market awareness regarding its products and services thereby being able to reach its target customers so easily. Internet platforms such as websites and social media sites enable one to receive feedbacks thus facilitating the company effort to improve its services delivery. During early days when the company was formed, people had trust issues with its online businesses. However, as time went on people noticed how placing orders and buying over internet platforms created convenience and flexibility. Since Alibaba was formed as an online business where it linked consumers and companies, it was bound to benefit as the country started going the internet-shopping way. People were realizing slowly how shopping from a credible online company would save them time; provide flexibility and convenience (Blank, 2017). Therefore, it can be concluded that internet resulted to the success Jack Ma is enjoying today. This is because the company took advantage of the large internet user in China to promote its brand, product and services. Since internet enables the users to provide immediate feedback, the company would keenly listen to the consumers' grievances and suggestions in enhancing their services. Jack Ma used the internet to undertake market survey and research, communicate to potential customers, and seek important market information, to provide goods and services and to enhance marketing (Legaspi, 2017). By effectively utilizing the internet, Alibaba Company is among the world's best internet companies. This is the reason why internet is said to have contributed to the success of various entrepreneurs in China.

China boosts of the largest number of online users in the world. It has also the fastest market of e-commerce in the world. With internet being one of the most used resources in China, it was expected that many Chinese will come up and invest in it. Apart from Alibaba, there are numerous other entrepreneurs in China who have succeeded because of internet usage (Legaspi, 2017). Ma Huateng is a very successful entrepreneur in China. Being a founder of Tencent Holdings which is the biggest publicly traded internet corporation, it is evident that internet played great role in his success. The share price of the company greatly rose thereby making him to rank in China as the wealthiest internet entrepreneur. This company has its key website-qq.com- which has made the company to stand in the top ten most popular sites in China. Robin Li who is the CEO and founder of Baidu online business is among the various Chinese entrepreneurs that have gained success due to internet. This 48 years old man went to study doctorate degree in USA related to computer science. He returned home and established Baidu alongside Erick Xu Yong (Legaspi, 2017). Ever since its establishment, the company has grown to become the most popular search engine. This company has hindered the entry effort and expansion of Google in the Chinese market. This entrepreneur offered internet related services including search engine and uses Chinese language as its main language.

Li's success as an entrepreneur is attributed to the internet usage in China. The entrepreneur realized a market opportunity and gap in the search engine business. Motivated by rising internet users within the country and the entire world, Li alongside his partner Erick Xu decided to establish Baidu in 1999 (Legaspi, 2017). Their decision and choice of the entrepreneur venture did not fail them. This is because, as more Chinese started embracing internet, the company continued to thrive in the Chinese Market. Majority of the population in China are Chinese-speaking people. Coming up with a search engine having main language being Chinese encouraged more Chinese to embrace and use the services of the company. The search engine is used by Chinese to look for information and undertake numerous online activities using its services. This is purely an online business. It is accessed via internet platforms or internet enabled devices such as computers and smartphones. Therefore, it can be concluded that Erick Xi owes his success to the growth and widespread of internet usage in China and across the entire globe.

In the entire world, China has the largest internet consumers. It has the most developing e-commerce in the market. Internet usage has led to emergence of numerous billionaires who have made it in the Forbes billionaire ranking lists. William Ding is an entrepreneur who ventured in online business (Bryant, 2015). Ding established an internet company that currently owns 45 percent of the game operator, NetEase which is an online game developer. It is the leading internet technology company in China. The company has always been dedicated in offering online services centered on community, content, commerce, communication and operates popular mobile games in China and also emails services. The company has also partnered with Mojang $\mathrm{AB}$ and Blizzard entertainment and many other global game developers in operating most popular international games in China. Being opportunistic enough and taking advantage of huge Chinese internet consumers, the company has been able to thrive in the internet business. Ding is listed among the 
richest Chinese people in the Forbes list. Serving millions of internet users in China has greatly contributed to his success.

Other key notable internet entrepreneurs in China include liu Qiaangdong who founded JD.com in China (Legaspi, 2017). Bearing in mind China is one of the fastest expanding major e-commerce market across the globe, Liu was bound to succeed in his online businesses. In his first business idea, he was distributing magneto-optical products in 1998. In 2004, he founded his first online business where he established online retail website. He later established JD.com in the same year. He is also listed in the Forbes list of billionaires in China. The entrepreneur also realized the opportunity in the online business (Legaspi, 2017). He observed and realized that internet is a key trend in the modern-day world and capitalized on that. This has led to the massive success he is enjoying today. Over half of the Chinese people are currently using internet to transact, search for information, shop and communicate. This large population has been instrumental in offering market for JD.com website.

Entrepreneurs such as Zhou Hongyi of Qihoo 360 technology is worth more than CEO of Yahoo Marissa Meyer. Qihoo is an internet security and search firm. Mo Tianquan is another success internet entrepreneur in China. This entrepreneur founded SonFun Holdings which is an online real estate information provider in China (Hayes, 2015). People interested in getting real estate information signs in to the company's website and all the latest information regarding real estate situation in China are present. Internet entrepreneurs in China proactively studied the market and saw the opportunity and came up with online businesses. Most of these entrepreneurs started investing in 1990 when internet was slowly gaining acceptance. Advancing technology provide various online platforms such as websites which were the main platforms used by online businesses in China (Hayes, 2015). Massive growth in technology coupled with rapid spread of internet contributed to success of all the above discussed Chinese entrepreneurs.

\section{General Significance of Internet on Businesses}

As established earlier in the study, internet has become part of our everyday life. Businesses and individuals are fully relying on the internet to undertake various tasks. People are using internet to look for information, communicate and play games. With the world going towards the digital age, internet remains one of the areas to venture in. Internet is playing greater roles in supporting business (Lee, 2007). It is through the internet that companies are able to communicate with their staff located in different parts of the world. Internet services such as emails, websites and social media sites are all becoming very instrumental in the survival of businesses. The messages conveyed to various intended users are received on instant basis and feedbacks are obtained so fast. Communication has greatly been enhanced by internet. Businesses are conducting meetings virtually through teleconferencing technologies. This enables people to conduct meetings and discussions over the internet and from diverse places across the world as if they are seated in the same conference hall (Bryant, 2015). Businesses are able to convey important information to consumers in an efficient and fast way through internet services. Consumers in the market are also able to obtain crucial information regarding the business. These are some of the reasons internet is said to have improved communication.

Internet is also playing crucial role in research. In the past, people relied on books, magazines, books and various publications in gaining knowledge. However, with growth and the spread of internet research it has been made easy. Search engines, websites, email services and social media sites are useful internet tools in enhancing and supporting research. Businesses are able to find consumer information online and strive to provide goods and products according to those needs (Bryant, 2015). Businesses are posting information regarding their products, services and their profiles on internet platforms. Consumers use internet to access the information of these companies. This ensures that both businesses and the consumers have right and updated information for transactions purposes. Through websites and social media platforms, businesses are able to access feedbacks and feelings of consumers regarding their products and services delivery. Businesses are able to undertake market research, understand consumer market and provide goods and services that are desired by consumers (Bryant, 2015).

Internet has enabled businesses to find ways to reduce costs of undertaking operations. For instant, businesses are implementing software to track operations and review efficiency of every department. Business managers are using these software packages to review information in a format of real-time and in more informed decisions. Access to information becomes cheaper and accessible in 24 hours. In the past, companies used to invest a lot of resources in various manual operations (Bryant, 2015). Businesses are improving their supply chain through communication to distributors, retailers and warehouse through internet as they are useful in handling the products of the company.

Internet is also helping businesses shorten their supply chain. In the traditional business environment, companies could not sell directly goods and services to the consumers (Hosu \& Iancu, 2016). Companies required having middlemen such as distributors, retailers and wholesalers in order to have their goods reach the end user. This was a long process as goods took more time to get to the final consumer and due to various exchange of hands from one intermediary to another, goods were made faulty and reduced in value. Longer supply chains means that the costs of the products will 
be high because every intermediary adds some amount to the price in order to get some form of profits. However, with emergence and widespread of internet usage, companies can now sell directly to the consumers (Blank, 2017). Individuals with access to internet can search products online from the companies' websites and place an order. The company receives such orders and plans how the consumer will receive the products. Therefore, internet has led to effective supply chain, reduced production costs, enabled easy and convenient access to information and improved the way businesses are operated.

\section{Conclusion}

Internet has become synonymous with almost every aspect of life. Many individuals in the present-day world rely on internet in undertaking different tasks. Internet is the product of the ever-advancing technology which has resulted to means of interconnecting various computers. Individuals can pay bills over the internet, purchase items, communicate and seek important information regarding various problems. Online purchase is the most common trend in the modern-day world. In China, internet has been a key factor in supporting emergence of numerous internet entrepreneurs in the world. For instance, Alibaba is an online business established by Jack Ma in 1999. The company has gained success due to the widespread usage of internet in China. Various entrepreneurs in China have been successful as a result of millions of internet users in China. China, with the largest population in the world and with majority of people using internet has greatly supported online business. More people in China will embrace internet and more internet entrepreneurs are expected to increase due to the ready market created by ever growing Chinese internet consumers.

\section{References}

Blank, C. (2017). Why the Internet Is Important in Business? Retrieved from https://bizfluent.com/about-5460932-internet-important-business.html

Bryant, B. (2015). What Are the Benefits of the Internet to Business? Retrieved from http://smallbusiness.chron.com/benefits-internet-business-316.html

DeLisle, J., Goldstein, A., \& Yang, G. (2016). The internet, social media, and a changing China. https://doi.org/10.9783/9780812292664

Donaldson, L. (2016). WHY THE INTERNET IS DRIVING ENTREPRENEURSHIP—AND WHAT IT MEANS FOR YOU.

Feng, C., \& Sun, W. J. (2017). China Now Has 751 Million Internet Users, Equivalent to Entire Population of Europe. Retrieved from https://www.caixinglobal.com/2017-08-07/101127296.html

Hayes, A. (2015). Top 10 Chinese Entrepreneurs.

Hosu, I., \& Iancu, I. (Eds.). (2016). Digital Entrepreneurship and Global Innovation. IGI Global. https://doi.org/10.4018/978-1-5225-0953-0

Lee, I. (2007). E-business innovation and process management. Hershey, PA: CyberTech Pub. https://doi.org/10.4018/978-1-59904-277-0

Legaspi, A. (2017). China's Top 10 Most Famous Internet Entrepreneurs. Retrieved from http://www.bitrebels.com/business/top-10-internet-entrepreneurs-china/

\section{Copyrights}

Copyright for this article is retained by the author(s), with first publication rights granted to the journal.

This is an open-access article distributed under the terms and conditions of the Creative Commons Attribution license which permits unrestricted use, distribution, and reproduction in any medium, provided the original work is properly cited. 